\title{
СОВРЕМЕННЫЕ ПОДХОДЫ К ОБУЧЕНИЮ РУССКОМУ ЯЗЫКУ КАК ИНОСЛАВЯНСКОМУ В БОЛГАРСКОЙ АУДИТОРИИ
}

Статья посвящена современным подходам к обучению русскому языку как инославянскому в болгарской среде. Рассмотрен дискурсивно-стилистический подход, основанный на дискурсивной теории межкультурной коммуникации. Современное дискурсивное, личностно-ориентированное обучение иностранных языков имеет деятельностно-творческий характер и направлено на индивидуальное развитие обучаемого в целях воспитания поликультурной личности на базе гуманистической педагогики и педагогической антропологии. Делается обзор научных достижений болгарской русистики в области разработки современных подходов к обучению русскому языку: межкультурного, контрастивного, социокультурного, лингвокультуроведческого, этнокультурного и когнитивно-прагматического.

Ключевые слова: русский язык как инославянский, болгарская методика преподавания русского языка, межкультурный подход.

The article deals with modern approaches to teaching Russian as another Slavic language in the Bulgarian environment. We discuss the discursive-stylistic approach that is based on the discursive theory of intercultural communication. The modern discursive, personality-oriented teaching of foreign languages possesses an activity-creative character and is directed towards the individual development of the student, in order to educate a multicultural personality on the basis of humanistic pedagogy and pedagogical anthropology. We give a review of scientific works of Bulgarian-Russian studies in the field of the development of modern approaches to teaching Russian in the Bulgarian environment, such as: intercultural, contrastive, socio-cultural, linguocultural, ethno-cultural, and cognitive-pragmatic.

Keywords: Russian language as another Slavic language, Bulgarian methodology of teaching the Russian language, intercultural approach.

В современной межкультурной лингводидактике на смену функциональностилистического подхода приходит дискурсивно-стилистический подход, основанный на дискурсивной теории межкультурной коммуникации, причем дискурсивное обучение русскому языку как иностранному (РКИ) имеет деятельностно-творческий характер и направлено на индивидуальное развитие обучаемого. В настоящее время творческое развитие болгарской методики преподавания русского языка как инославянского - РКИ инсл. (на основе теории проф. Боголюба Станковича о РКИ инсл.) осуществляется в сочетании межкультурного, контрастивного, социокультурного, этнокультурного, лингвокультуроведческого и когнитивно-прагматического подходов к иноязычному, личностно-ориентированному обучению на базе гуманистической педагогики и педагогической антропологии, психолингвистики и социолингвистики (Лесневская 2018б). Преподавание РКИ инсл. (Станкович 2010) в Болгарии осуществляется на базе общеславянской лексики, различение видов глагола и др. - т.е. используется положительная интерференция. Исходя из положительного переноса, акцент ста- 
вится на преодоление отрицательной интерференции: в отличие от синтетического строя русского языка болгарский язык обладает аналитическим строем.

В соответствии с принципом минимизации и цикличности (Лесневская 1986), а также с комплексно-концентрическим принципом обучения русской лексике в инославянской аудитории Е. Марковой на основе проделанного теоретического исследования ${ }^{1}$ выделяются три концентра-уровня когнитивного изучения лексики в процессе поэтапного, последовательного подхода преподавания РКИ инсл.: денотативный, системный и концептуальный уровни смысловой структуры лексики близкородственных, славянских языков. Третий, высший уровень семантики - концептуальный - связан с этнокультурой и основан на этнокультурологическом и лингвокультурологическом подходах к обучению РКИ инсл. (Маркова 2018). Сравн. различия в фразелогизмах для выражение череды бед в межславянском диалоге культур: рус. из огня да в полыля; болг. от трън та на глог; словац. z blata do kaluže ; серб. с коња на магарияа.

В последние годы в болгарской методике русского языка утвердился инновационный межкультурный подход (Тарева 2017б), реализующий осуществление диалога равноправных культур в межкультурном русско-болгарском общении - диалога между культурой изучаемого, русского языка и культурой родного, болгарского языка (Лесневская 2017б). Культура - ключевой концепт современной лингводидактики (Тарева 2017a). Овладение межкультурной компетенцией осуществляется на различных уровнях (когнитивном, аффективном, коммуникативно-поведенческом) через межкультурное иноязычное образование, имеющее целью формирование межкультурных личностей (Бердичевский 2016). Метод диалога культур при обучении иностранному языку (культура через язык и язык через культуру) исследован Е.И. Пассовым².

Инновационное паритетное взаимодействие двух культур предусматривает следующую совокупность действий: знакомство с фактом иной культуры - перенос его в родную культуру и осознание ее особенностей - переоценка факта родной культуры - постижение с этих позиций явления иной культуры - переоценка факта иной культуры» (Тарева 2014).

Новые методические положения межкультурного подхода предполагают синергию смыслов и гармонизацию переводческого пространства в процессе гармоничного перевода (Кушнина 2014) в целях создания полилингвальной языковой личности в соответствии с современной языковой средой и речевой культурой. В болгарской лингводидактике детально исследуются переводческие трансформации с русского на болгарский язык и с болгарского на русский язык в процессе двуязычной коммуникации на основе билингвизма (Томанова 2009). Выделяются типичные ошибки в учебном переводе художест-

${ }^{1}$ См.: Лесневска Д.С. Рецензия: Маркова Е.М., Григорянова Т. Динамические аспекты лексики современных славянских языков. Brno: Tribun EU, 2016, 187. Русистика без граници 3, 2017, 76-80. Авторы приходят к выводу о конвергентном характере развития лексиконов славянских языков, что содействует использованию положительной интерференции (положительного переноса) при изучении русского языка как инославянского в славянской среде, в частности в болгарской.

${ }^{2}$ См. Пассов Е.И. Метод диалога культур. Экскиз-размылиление о развитии методической науки. Липецк, 2011. 
венных текстов в процессе обучения РКИ инсл. в целях преодоления отрицательной интеференции на синтаксическом уровне, напр.: «У него, лишивщегося в детстве родителей, никого больше не было. - буквальный ошибочный, учебный перевод: Той, загубил родителите си като дете, нямаше никого другиго. - Редакция: Той беше загубил родителите си като дете и нямаше никого другиго.» (Христова 2018: 483). Для иноязычного обучения и хорошего владения родным, болгарским языком Институт болгарского языка им. проф. Л.. Андрейчина, БАН, периодически выпускает учебные терминологические толково-сочетаемостные словари (Лесневская 2017г), активно исследуются также взаимоотношения русской и болгарской терминосистем (Симеонова 2017).

При обучении РКИ инсл. в болгарской среде для осуществления инновационного равноправного диалога культур применяется контрастивный, сравнительно-сопоставительный подход: русские речевые модели сравниваются и сопоставляются с болгарскими речевыми клише. Дискурсивное обучение направлено на формирование прагмалингвистической компетенции как основного компонента межкультурной коммуникативной компетенции в русле равноправного диалога родной и иноязычной культур. Прагмалингвистическая компетенция представляет собой способность ориентироваться в коммуникативно-прагматическом пространстве и правильно использовать правила речевого поведения в конкретной ситуации общения, адекватно совершать коммуникативный акт (совокупность речевых актов). В иноязычном обучении для реализации равноправного диалога необходимо сопоставление языковых форм изучаемого и родного языков, в частности русского и болгарского языков при осуществлении дискурсивного обучения РКИ инсл. в болгарской среде, напр.: косвенные перформативы - вежливые просьбы, «замаскированные» риторические вопросы типа рус. Вы не могли бы посетить эту выставку. / болг. Дали бихте могли да посетите тази изложба? (Лесневская 2017в: 125).

Болгарская методика русского языка восприняла научную школу $\mathrm{B}$. Сафоновой в области педагогической социокультуралистики и концепции социокультурного подхода к обучению иностранным языкам (Сафонова 2017). В. Сафоновой сформулированы новые методические положения о соизучении иностранного языка и культуры, а также создана инновационная учебная и учебно-методическая литература, построенная на многоуровневой модели изучения инностранных языков в контексте диалога культур и цивилизацийㄱ.

Социокультурная компетенция состоит из общекультурной осведомленности, культуроведческой и лингвокультуроведческой компетенций, социолингвистической и социально-стратификационной компетенций (Сафонова 2014).

${ }^{3}$ См.: Лесневска Д.С. Рецензия: Базина Н. В., Сафонова В. В. Метро, троллейбус, трамвай - читай, используй, изучай. Москва: НИЦ „Еврошкола“, 2016. - 48 с., Русистика без граници 3, 2017, 81-84. Данное учебное пособие реализует принцип диалога культур и цивилизаций средствами соизучаемых языков при обучении РКИ посредством интерактивных методов (межкультурный диалог, межкультурные ситуации общения), познавательно-поисковых социолингвистических, культуроведческих и лингвокультуроведческих проблемных заданий; в нем находят реализацию интернет-ориентированная методика иноязычного обучения, когнитивные аспекты овладения культурой; предлагаются небольшие связные тексты-дискурсы в комбинации с экстралингвистическими факторами - полифункциональными иллюстрациями, схемами и таблицами. 
В русле межкультурной парадигмы В. Сафоновой болгарский русист И. Бирова проводит исследования игры в обучении РКИ в болгарской аудитории (Бирова 2017). Для формирования социокультурной компетенции в болгарской лингводидактике используется биографический метод в комбинации с коммуникативным методом (Капинова 2013).

Для социокультурной концепции болгарской методики русского языка востребованы результаты научных исследований членов болгарского Международного социолингвистического общества (его почетный председатель - известный болгарский языковед, акад. Михаил Виденов) ${ }^{4}$.

В процессе обучения РКИ инсл. в болгарской среде активно используются этнокультурный и лингвокультуроведческий подходы на базе теоретических исследований русских и болгарских этноединиц и этнофразем, напр. прозвищ, возникших на базе реальных лиц, таких как болг«Марко Тотев» невезучий; болг. «Гюро Михайлов» - простодушно-исполнительный, наивный человек, болг. «Бай Ганьо» - представитель болгар с отрицательными чертами (Георгиева 2018: 376-378), а также на базе русской и болгарской лингвокультур (Манова 2016). На основе теории славянской, в частности русской фразеологии В. Мокиенко, В. Телия, Н. Толстого, А. Шмелева и др. сопоставительному анализу подвергаются темпоральные фразеологизмы в болгарском и русском языках, сравн. рус. «Делу - время, а потехе - час» - болг «Отделяй повече време за работа, а не за развлечения» (Георгиева 2016: 436).

Разработана также лингвокультурологическая тема «Русские памятники - значимое культурное и архитектурное наследие Болгарии, Софии» в рамках обоучения РКИ инсл. в болгарской аудитории (Лесневска Р., Лесневска Д. 2015). Для болгарской аудитории интерес представляет исследование русских памятников Русско-турецкой освободительной войны 1877 - 1878 гг. с лингвокультурологической точки зрения. Новая дискурсивная теория межкультурной коммуникации, согласно которой язык и культура представляют собой единый интегративный объект, является исходной теоретико-методической основой данного исследования. Защита русских памятников в Болгарии, в частности, в столице Софии, - актуальная задача и национальная ответственность всего болгарского общества. Целью исследования является рассмотрение русских памятников в Софии в хронологическом порядке: начиная с Русского памятника (1882) и кончая памятником генералу И. В. Гурко (2013). Основная тема русских памятников - прославление народной признательности. В Болгарии есть свыше 450 русских памятников, которые посвящены русским освободителям. «Русские памятники» - часть культурно-исторического богатства Болгарии. Первый,самый древний памятник, построенный в столице Княжества Болгарии по дороге, по которой Осман Нури паша покидает Софию по направлению в Перник - это Русский памятник (1882). Самый новый столичный «русский памятник» - это памятник в честь освободителя Софии - генерала Гурко (2013). Считаем, что

${ }^{4}$ См: Симеонова К. За някои промени в социалната оценка и отношението на обществото към термините. [В:] Проблеми на социолингвистиката. Кирил Цанков (ред.), София: МСД, Т.11, 2014, 464- 469; Р. Алтимирска. Социално-психологическите параметри на езиковото клише. [В:] Светът е слово, словото е свят. Благоевград: Унив. изд., 2016, 183-190. 
тема «Русские памятники в Софии 1882 - 2015 гг.» может стать основой будущей учебной программы в рамках национального форума «Культура Болгарии» в связи с интегрированием Софии в Европейское культурно-историческое наследие. Язык архитектуры является актуальной темой болгарских исследований в области искусствоведения, культурологии, истории, лингвокультурологии 5 .

С межкультурным и контрастивным подходами к обучению РКИ инсл.в Болгарии удачно сочетаются коммуникативно-прагматический, когнитивнопрагматический, лингвотеатральный и суггестопедический подходы ${ }^{6}$.

Разработано в теоретическом и практическом планах обучение русскому эпистолярному дискурсу в болгарской аудитории (Лесневская 2017а, 2017г, 2018a). По прагмалингвистической установке (типы речевых актов, в состав которых входят перформативные глаголы) разграничиваются следующие жанры деловых писем: извещение, напоминание, подтверждение, предложение, просьба, гарантия, запрос, ответ на запрос, заказ, отказ, предупреждение, приглашение, ответ на приглашение, благодарность, поздравление, извинение, сожаление и др. Для эпистолярного дискурса русских и болгарских деловых писем характерными являются следующие типы речевых актов (по классификации Дж. Серля и Ю. Д. Апресяна): 1. Ассертивы; 2. Комиссивы; 3. Директивы; 4. Декларативы; 5. Экспрессивы. Выделяем следующие модели речевого поведения русских и болгарских деловых писем в рамках прагмалингвистики: сообщение (набор ассертивов); обещание (набор комиссивов); просьба, предложение, рекламное письмо, приглашение, совет, предупреждение, напоминание, требование, запрет, разрешение (набор директивов); подтверждение, отказ, декларация, объявления (набор декларативов); благодарность, извинение, поздравление, прощание, пожелание, сожаление, надежда (набор экспрессивов).

В рамках когнитивно-прагматической парадигмы ${ }^{7}$, деловые письма подразделяются на следующие типы в зависимости от коммуникативной цели, дискурсивной стратегии и набора концептов (обязательство/отсутствие обязательства; необходимость/ отсутствие необходимости; польза, требование, известие, потребность, выгода/отсутствие выгоды; оценка, доверие, надежность, связи): ин-

${ }^{5}$ См: Диамандиева М. Съвременната архитекутра като масова комуникация: «отвъд» архитектурата или разтегната медийна реалност. [В:] Изкуствоведски четения. София: БАН. Институт за изследване на изкуствата, 2013; Исса К. Езикът и архитектурата. Езикът на архитектурата. [В:] Проблеми на социолингвистиката. София: МСД, 2014, 348-354.

${ }^{6}$ См.: Карпенко Л. Коммуникативно-прагматический комплекс в преподавании русского языка как иностранного. Русистика без граници 4, 2017, 83-87; Лесневская Д. Когнитивно-прагматическая харакетристика эпистолярного дискурса (на материале русских и болгарских деловых писем ). Доклад (в печати). [Заочное участие в Межд. Конференции МГОУ, Москва, 24-25 ноября 2017 г. «Рациональное и эмоциональное в русском языке»]; Цотова Д. К вопросу о разработке микротекстов в контексте применения лингвотеатрального подхода для преподавания русского языка как иностранного. [В:] Русистика сегодня: традиции u nерспективы. София: Тип-топ прес, 2017, 448-455; Пыркова Т. Театрализация в формировании лингвистической компетенции. [В:] Потенщиал современной науки 7, 2014; Любенова И. О болгарском методе „суггестопедия“ и о поиске лучшего метода изучения иностранных языков. [В:] Сб. МАПРЯЛ: Десятый международный симпозиум. Велико Тырново, 2010, $569-572$.

${ }^{7}$ См.: Шеина И. Единищы и способы языковой концептуализации в деловом письме. Рязань: РГУ, 2012, 340 с. 
формационные письма; письма, побуждающие адресата совершить действие; письма, содержащие требование или претензию; письма, сообщающие о принятом решении; письма, содержащие обязательства, подтверждение, гарантии; этикетные письма.

Ядерная структура эпистолярного делового дискурса включает в себя ядро, где размещаются регламентированные письма с наибольшей стандартизованностью (письма, содержащие требование или претензию: требование, рекламация); средний уровень занимают информационные письма: уведомление, извещение, напоминание и др.; на периферии, характеризующейся наименьшей стандартизованностью, располагаются информационные рекламные письма и этикетные письма. На основе перечисленных классификаций деловых писем, в частности торговых писем, созданы списки моделей речевого поведения русских и болгарских деловых писем, которые используются в качестве учебного материала при преподавании русского бизнес-языка, проведении деловых игр при обучении РКИ в болгарской аудитории, сравн.: рус. Благодарим Вас за запрос от 15 апреля. - болг. Благодарим Ви за запитването от 12 март; рус. Мы готовы с Вами сотрудничать. - болг. Ние сме готови да сътрудничим с Вас; рус. Я должен извиниться перед Вами. - болг. Длъжен съм да Ви се извиня; Трябва да Ви се извиня.

Итак, культурообразующая, антропоцентричная концепция современного языкового образования обосновывает рассмотренные подходы к обучению русскому языку как инославянскому в болгарской методике русского языка: дискурсивностилистический, межкультурный, контрастивный, этнокультурный, социокультурный, лингвокультурологический и когнитивно-прагматический. По нашему мнению, при преподавании русского языка в болгарской среде необходимо учитывать общую, базовую славянскую культуру и родственность славянских языков, приводя примеры не только на русском и болгарском, а на всех славянских языках.

\section{Цитирана литература}

Бердичевский, Анатолий. «Как написать современный межкультурный учебник иностранного языка». Иностранные языки в школе 10, 2016:12-18.

Бирова, Илка. Игра в обучении русскому языку как иностранному. Москва: НИЦ «Еврошкола», 2017.

Георгиева, Ирина. «Темпоралните фразеологизми през призмата на българския и руския език». Светът е слово, словото е свят. Благоевград: Унив. изд., 2016, 429-440.

Георгиева, Стефка. «Национальные образы в зеркале языковых образов». В. Аврамова, А. Пенчева, Г. Гочев, С. Георгиева, И. Владова, В. Николова (ред.). Русистика: вчера, сегодня, завтра. София: Общество русистов Болгарии, 2018, 371- 383.

Капинова, Елина. «Биографический метод в обучении русскому языку студентов-нефилологов». Перспективы науки и образоавния 4, 2013, 114-118.

Кушнина, Людмила. «Принципы гармоничного перевода: метапереводческий аспект». М. Котюрова (ред.). Стереотипность и творчество в тексте. Пермь: ПГНИУ, № 18, 2014, 65-76. 
Лесневская, Димитрина. «Минимизация на учебния материал и цикличност при обучението по руски език на чуждестранните студенти». Проблеми на учебно-възпитателната работа по чужди езици с чуждестранни студенти. Варна: ВИНС, 1986, 86-90.

Лесневская, Димитрина. «Традиции и современное состояние исследований делового русского языка в болгарской русистике». К. Кончаревич (ред.) Университетская славистика: традиции, современное состояние, перспективы. Београд: Филолошки факултет, 2017a, 475-487.

Лесневская, Димитрина. «Новое и традиционное в болгарской методике преподавания русского языка как иностранного». В. Аврамова, И. Владова (ред.). Болгарская русистика. Альманах. Болгария 2017. София: Фонд «Славяне», 2017б, 176-189.

Лесневская, Димитрина. «Метод контрастивного изучения моделей речевого поведения в межкультурном иноязычном образовании». М. Котюрова (ред.). Стереотипность и творчество в тексте. Пермь: ПГНИУ, № 21, 2017в, 122-130.

Лесневская, Димитрина. «Эпистолярный дискурс в обучении русскому языку как иностранному в болгарской аудитории». А. Вачева, Т. Алексиева, Ц. Ралева, А. Радкова, К. Петрова, Н. Нечаева, И. Чекова (сост.). Русистика сегодня: традиции и перспективы. София: Тип-топ прес, 2017г, 390-396.

Лесневская, Димитрина. «Учебен терминологичен тълковно-съчетаемостен речник за целите на чуждоезиковото обучение». Е.Петкова, М. МихайловаПаланска, С. Колковска (ред.). Езикът на науката и науката за езика. Юбилеен сборник в чест на чл.-кор. проф. д.ф.н. Мария Попова. София: Издателство на БАН «Проф. Марин Дринов», 2017д, 160-170.

Лесневская, Димитрина. «Диалог культур на занятиях по деловому русскому языку в болгарской аудитории». В. Аврамова, А. Пенчева, Г. Гочев, С. Георгиева, И. Владова, В. Николова (ред.). Русистика: вчера, сегодня, завтра. София: Общество русистов Болгарии, 2018a, 713-719.

Лесневская, Димитрина. «Обучение русскому языку как иностранному в инославянской болгарской аудитории». Г. Скнар, Н. Тропина, Н. Мулатова (ред.). Актуальные проблемы межкультурной коммуникации. Ростов-на-Дону: РГМУ, 20186, 57-60.

Лесневска, Радослава, Димитрина Лесневска.«Русские памятники - значимое культурное и архитектурно-историческое наследие Софии». Научный вестник ВГАСУ. Лингвистика и межкультурная коммуникация. № 4 (18), 2015: 234-238.

Манова, Ирина. «Концепт «персик» в русской и болгарской лингвокультурах». Болгарская русистика 1, 2016: 66-76.

Маркова, Елена. «Русская лексика в инославянской аудитории: лингвокогнитивный и лингвометодический аспекты». Русистика: вчера, сегодня, завтра. София: Общество русистов Болгарии, 2018, 720-726.

Сафонова, Виктория. «Социокультурный подход: основные социально-педагогические и методические положения». Иностранные языки в школе 11, 2014: 2-13.

Сафонова, Виктория.«Культуроведческие основы изучения русского языка в поликультурном пространстве современного мира». Русистика сегодня: традиции и перспективы. София: Тип-топ прес, 2017, 417-425.

Симеонова, Кристияна. «За някои българо-руски терминологични успоредици». Е.Петкова, М. Михайлова-Паланска, С. Колковска (ред.). Езикът на на- 
уката и науката за езика. Юбилеен сборник в чест на чл.-кор. проф. д.ф.н. Мария Попова. София: Издателство на БАН «Проф. Марин Дринов», 2017, $246-252$.

Станкович, Боголюб. «Актуальные вопросы изучения и преподавания русского языка как инославянского». Г. Гочев (ред.). МАПРЯЛ 2010. Десятый международный импозиум. Велико-Търново: Унив. Изд., 2010, 11-14.

Тарева, Елена. «Культура как ключевой концепт лингводидактики». Русистика без граници. Международно научно списание 1, 2017a: 88-97.

Тарева, Елена. «Межкультурный подход в системе лингводидактических инноваций». Русистика без граници. Международно научно списание 3, 2017б: $25-30$.

Тарева, Елена. «Паспортизация лингводидактических инноваций : постановка проблемы». Г. Гочев (ред.). МАПРЯЛ 2014. Одиннадцатый Международный симпозиум. Велико-Търново: Унив. Изд., 2014, 500-504.

Томанова, Светла. Междуезиково взаимодействие в превода. Благоевград: Унив.изд., 2009.

Христова, Наталия. «Интерференция на синатксическом уровне в учебном переводе художественных текстов». В. Аврамова, А. Пенчева, Г. Гочев, С. Георгиева, И. Владова, В. Николова (ред.). Русистика: вчера, сегодня, завтра. София: Общество русистов Болгарии, 2018, 480-486.

Димитрина Лесневска

\section{САВРЕМЕНИ ПРИСТУПИ НАСТАВИ РУСКОГ ЈЕЗИКА КАО ИНОСЛОВЕНСКОГ У БУГАРСКОЈ СРЕДИНИ}

\section{Резиме}

У раду се спроводи анализа приступа настави руског језика као инословенског у бугарској средини. Савремена методика наставе руског језика као страног у бугарској средини представља саставни део методике језичког образовања у Бугарској. Бугарска методика руског језика разрадила је и инкорпорирала у наставни процес дискурсивно-стилистички, интеркултурални, социокултурални, етнокултурални, лингвокултуролошки и когнитивно-прагматички приступ у учењу руског језика као страног. Узимају се у обзир одлике наставе руског језика као инословенског у словенској (бугарској) средини.

Кључне речи: руски језик као инословенски, бугарска методика наставе руског језика, интеркултурални приступ. 